\title{
Prevalence of ABO and RH Blood Group and Sub-Group A1 and A2 in Blood Donors of Odisha - Experience of One Tertiary Centre
}

Pradhan PK, Mishra SC, Patnaik BK and Mohanty $\mathrm{D}^{*}$

Department of Transfusion Medicine, Apollo Hospitals Bhubaneswar, Odisha, India

\begin{abstract}
The paucity of report from Odisha regarding prevalence of $\mathrm{ABO}$ and $\mathrm{Rh}$ blood group promoted us to undertake the present retrospective study. Total number of subjects studied are 45,564. Prevalence rate of $A, B$ and $O$ are 9679 (21.24\%), $13881(30.46 \%)$ and $16662(36.56 \%)$ respectively. The subgroup analysis showed of A1 and A2 has also been carried out in the present study. One case of A2 has been described which had antibody to $A 1$ where there was difficulty in arranging the blood transfusion insisting there by the importance of subgroup analysis in the blood bank.
\end{abstract}

Keywords: Blood group; Population; Blood donors

\section{Introduction}

India is a vast country and the population is genetically heterogenous. Therefore, the blood group distribution especially ABO and $\mathrm{Rh}$ varies from one to the other state [1-4]. There is no published report on $\mathrm{ABO}$ and $\mathrm{Rh}$ blood group from Odisha. Odisha consists of $23 \%$ of ST and $17 \%$ of SC population and rest is of general caste.

Therefore, the present communication is an attempt of one tertiary care centre i.e. Apollo Hospitals, Bhubaneswar, Odisha to report the distribution of $\mathrm{ABO}$ and $\mathrm{Rh}$ with special reference to $\mathrm{A} 1$ and $\mathrm{A} 2$ subgroup of the Odisha population. People from different parts of Odisha are attending this hospital. Hence, it represents almost all the districts of Odisha.

Furthermore we have tried to emphasize in this present paper the need of A1 and A2 Distribution in our state, the importance of which many transfusion medicines personal do not realize, Attempt has been made therefore to highlight the importance of A1 and A2 sub Group. We innumerate here one case involving this problem:

\section{Case Report}

A 28 years female was admitted in the year 2015 to Apollo Hospitals Bhubaneswar with severe anemia (Hb-4.2 g/dL) for Blood Transfusion. The clinician requested for 2 units of PRC. While doing grouping and cross matching in the patients sample following are the observations (Figure 1).

Negative reaction with anti A1 lectin indicates it is not group A1. However, +++ reaction with Anti $\mathrm{H}$ suggests A sub group, but not A1 or A intermediate. Positive reaction with A1 cell indicates the presence of atypical antibody.

\section{Forward Typing}

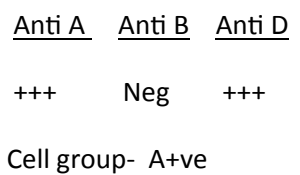

Anti A1 lectin Anti $\mathrm{H}$

Negative +++

Figure 1: Observations of the patient's sample.
To confirm this test results serum grouping with A2 and $\mathrm{O}$ cell with Auto control was done. The test for atypical antibody was also carried out which showed the absence of atypical antibody. This confirms that the patient belongs to sub- group A2 with A1 antibody.

To confirm these results cross match was done with A2, A1 and $\mathrm{O}$ packed red cells, Both $\mathrm{A} 2$ and $\mathrm{O}$ packed red cells are compatible, whereas A1 packed red cell was incompatible by both Tube and Cat technique. Depending on these results, we transfused one unit of A2 packed red blood cell to the patient without any untoward reaction.

\section{Methodology}

For the present study we adopted the Following methods.

A total of $3 \mathrm{ml}$. of blood sample was collected pre donation in EDTA vial and one plain vial for clotted sample with the Unique Identification Number. ABO and Rh blood grouping was performed for each sample in Tube and Column Agglutination Technique. (Ortho clinical Diagnostics UK).

The reagent used was Anti A, Anti B, Anti AB, Anti D1 and Anti D2 manufactured by Tulip Diagnostics (P) Ltd. The A Cell, B Cell, and O Cell suspension was prepared in-house. All reagents were subjected to Quality control test including Titer and Avidity for each new lot used.

$\mathrm{ABO}$ grouping $\mathrm{A}$ and $\mathrm{AB}$ Sub group $\mathrm{A} 1, \mathrm{~A} 2, \mathrm{~A} 1 \mathrm{~B}$ and $\mathrm{A} 2 \mathrm{~B}$ depending upon the reaction with A1 Lectin (Dolichus Biflorus) was also carried out [5-7].

The sample size of our study is 45,564 ; out of which 20,750 blood donors and 24,814 are recipients. Age of the subjects varies from 18 years to 65 years.

*Corresponding author: Mohanty D, Department of Transfusion Medicine, Sr. Consultant Hematologist and Chief of Lab Services, Apollo Hospitals Bhubaneswar, Odisha, India, Tel: 8093060025; E-mail: drmohantydipika09@gmail.com

Received June 19, 2019; Accepted June 28, 2019; Published July 03, 2019

Citation: Pradhan PK, Mishra SC, Patnaik BK, Mohanty D (2019) Prevalence of $\mathrm{ABO}$ and $\mathrm{RH}$ Blood Group and Sub-Group A1 and A2 in Blood Donors of Odisha Experience of One Tertiary Centre. J Blood Lymph 9: 249.

Copyright: @ 2019 Pradhan PK, et al. This is an open-access article distributed under the terms of the Creative Commons Attribution License, which permits unrestricted use, distribution, and reproduction in any medium, provided the original author and source are credited. 
Citation: Pradhan PK, Mishra SC, Patnaik BK, Mohanty D (2019) Prevalence of ABO and RH Blood Group and Sub-Group A1 and A2 in Blood Donors of Odisha - Experience of One Tertiary Centre. J Blood Lymph 9: 249.

\section{Observation}

\section{Prevalence of $\mathrm{ABO}$ and its subgroup}

In our five years study from 2011 to 2015 we have found highest number of donors and patients from Central Division of Odisha in comparison to the Northern and Southern parts of odisha (Figure 2a and $2 \mathrm{~b}$ ).

When the total number of subjects were divided to Donors and recipients (patients) there is not much change in the distribution of $\mathrm{ABO}$ and Rh blood group system Table 1a. The subgroup of ABO i,e
$\mathrm{A} 1$ and $\mathrm{A} 2$ have been shown in Table 1b. It can be noticed that A2+ve subjects vary from 0.11 to 1.94 , where as $\mathrm{A} 1+$ ve vary from 20.31 to 0.11 .

\section{Weak $\mathrm{D}$ prevalence in blood donors and patients}

The prevalence of $\mathrm{Rh}$ blood group system is shown in Table 2. It is observed 03 subjects $(0.014 \%)$ are weak D positive. We also studied the $\mathrm{Rh}$ negative recipients in different subgroups of $\mathrm{ABO}$ system. In total 15 recipient were found to have weak $\mathrm{D}$ (Table 3). According to different $\mathrm{ABO}$ blood group the distribution of Weak D is shown in Table 4. It is observed that the percentage of Weak D is more in Recipients than the blood Donors.
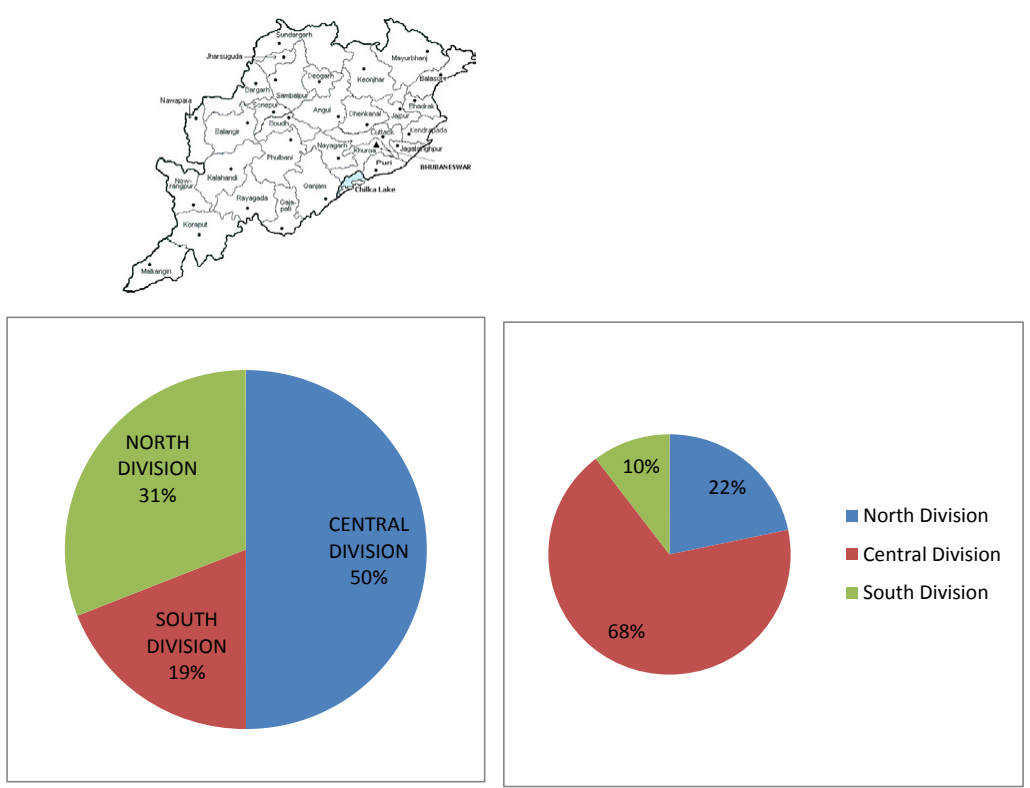

Figure 2: $(a$ and $b)$ Division wise distribution of donors and patients.

\begin{tabular}{|c|c|c|}
\hline & Total Number of Patients $(\mathbf{n}=\mathbf{2 4 8 1 4 )}$ and Donors $(\mathbf{n}=\mathbf{2 0 7 5 0 )}$ from the year 2011 to 2015 \\
\hline Blood Group & Number of patients with (\%) & Number of Donors with (\%) \\
\hline A+ve & $5141(20.71)$ & $4538(21.86)$ \\
\hline B+ve & $7471(30.10)$ & $6410(30.89)$ \\
\hline O+ve & $9430(38.002)$ & $7232(34.85)$ \\
\hline AB+ve & $1577(6.35)$ & $1617(7.79)$ \\
\hline A-ve & $288(1.16)$ & $210(1.01)$ \\
\hline B-ve & $343(1.38)$ & $326(1.57)$ \\
\hline O-ve & $474(1.91)$ & $335(1.61)$ \\
\hline AB-ve & $88(0.35)$ & $80(0.38)$ \\
\hline Oh+ve & $02(0.008)$ & $2(0.009)$ \\
\hline
\end{tabular}

Table 1a: $\mathrm{ABO}$ and Rh blood group system.

\begin{tabular}{|c|c|c|}
\hline \multicolumn{2}{|c|}{ Total No of Patients $(\mathbf{n = 2 4 8 1 4 )}$ and Donors $(\mathbf{n = 2 0 7 5 0 )}$} \\
\hline Sub-Group & Number of patients with (\%) & Number of Donors with (\%) \\
\hline A1+ve & $4658(18.77)$ & $4216(20.31)$ \\
\hline A2+ve & $483(1.94)$ & $322(1.55)$ \\
\hline A1B+ve & $1388(5.59)$ & $1418(6.83)$ \\
\hline A2B+ve & $189(0.76)$ & $199(0.95)$ \\
\hline A1-ve & $141(0.56)$ & $237(1.14)$ \\
\hline A2-ve & $11(0.04)$ & $51(0.24)$ \\
\hline A1B-ve & $33(0.13)$ & $64(0.30)$ \\
\hline A2B-ve & $7(0.02)$ & $24(0.11)$ \\
\hline
\end{tabular}

Table 1b: The subgroup of $A B O$ i.e. $A 1$ and $A 2$. 


\begin{tabular}{|c|c|c|}
\hline \multicolumn{3}{|c|}{ Total No of Donors $(\mathbf{n}=\mathbf{2 0 7 5 0 )}$} \\
\hline Number of Donors & Blood Group & Percentage (\%) \\
\hline 19916 & Rh+ve & $95.98 \%$ \\
\hline 831 & Rh-ve & $4.00 \%$ \\
\hline 3 & Weak D+ve & $0.014 \%$ \\
\hline
\end{tabular}

Table 2: The prevalence of Rh blood group system.

\begin{tabular}{|c|c|c|}
\hline \multicolumn{3}{|c|}{ Total Number of Rh Negative Recipients from the year 2011 to $2015(\mathbf{n = 1 2 0 8 )}$} \\
\hline Number of recipients & Blood Group & Percentage (\%) \\
\hline 288 & A-ve & $23.841 \%$ \\
\hline 343 & B-ve & $28.394 . \%$ \\
\hline 474 & O-ve & $39.238 \%$ \\
\hline 88 & AB-ve & $7.284 \%$ \\
\hline 15 & Weak D+ve & $1.241 \%$ \\
\hline
\end{tabular}

Table 3: Rh negative recipients in different subgroups of $A B O$ system.

\begin{tabular}{|c|c|c|c|}
\hline No. of Patient & Blood Group & Weak D & Percentage (\%) \\
\hline 288 & A-ve & 8 & $2.777 \%$ \\
\hline 343 & B-ve & 3 & $0.874 \%$ \\
\hline 489 & O-ve & 3 & $0.613 \%$ \\
\hline 88 & AB-ve & 1 & $1.136 \%$ \\
\hline
\end{tabular}

Table 4: Different $A B O$ blood group the distribution of Weak $D$.

\section{Discussion}

The present study is an attempt to find out the frequency of $\mathrm{ABO}$ and $\mathrm{Rh}$ blood group antigens and their sub group in Odisha population since no published report from Odisha was found. This is very well known that $\mathrm{ABO}$ and $\mathrm{Rh}$ phenotypes vary widely in different ethnic populations and countries [8]. Our observation about frequency of $\mathrm{Rh}$ negative donors is similar to Chandra and Gupta 2012 [9]. Indian population is a heterozygous one and some published reports about blood group distribution are available from different states which varies in their gene frequency [10].

The Rh system is second only to the ABO system in importance in Transfusion medicine because of $\mathrm{Rh}$ antigens, especially $\mathrm{D}$, are highly immunogenic and can cause hemolytic disease of the newborn (HDN) and severe transfusion reactions. The Rh system has long been acknowledged as one of the most complex blood group systems because of its large number of antigens and the heterogeneity of its antibodies [6]. An estimated $0.2 \%$ to $1 \%$ of white persons (and a greater number of African Americans) have reduced expression of the D antigen [7].

Our study shows "O" Rh+ve to be the most prevalent one followed by 'B' Rh+ve (Table 1A). This is similar to the reported frequency in South India [2] and differs from the published reports in north Indian population [10].

The prevalence of $\mathrm{Rh}(\mathrm{D})$ reported in the present study is very similar to that reported by $[1,11,12]$. The present study deals with the importance of sub group of A determination in the transfusion medicine practice as illustrated by our case report. In fact this case prompted us to determine the sub group of $\mathrm{A}$ in the donor and patient population of our hospital. The subgroup of A (A1 and A2) was discovered after discovery of Dolichus Biflorus by BIRD in the year 1952 [8]; later on rarer subgroup A3 was also added to the series. Prevalence of A1 and A2 found to be in the proportion of $80 \%$ and $20 \%$ respectively in the western population [13]. The A2 antigen is a weaker one compared to A1; because of the weaker antigenic power of A2, hemolytic transfusion reaction is not severe or lethal under normo thermic situation. However severe reaction may occur due to presence of anti $\mathrm{A} 1$ at lower temperature i,e approximately $25^{\circ} \mathrm{C}$ or below as has been reported in a case of CABG under hypothermic condition [14]. In the present study the prevalence of $\mathrm{A} 1$ and $\mathrm{A} 1 \mathrm{~B}$ and $\mathrm{A} 2$ and $\mathrm{A} 2 \mathrm{~B}$ in donors and patients are shown (Table 1B). In another previous study done in north Karnataka region by Sujatha et al. the prevalence of A1 and $\mathrm{A} 1 \mathrm{~B}$ in donors was $25.91 \%$ and $7.34 \%$ and $\mathrm{A} 2$ and $\mathrm{A} 2 \mathrm{~B}$ was $0.30 \%$ and $0.85 \%$ respectively [15].

In a study done in the Muslim population of Uttar Pradesh (UP) by Hussain et al. The prevalence of A1 and A1B was $26.52 \%$ and $19.34 \%$ and $\mathrm{A} 2$ and $\mathrm{A} 2 \mathrm{~B}$ was $2.90 \%$ and $1.24 \%$ respectively [4]. Their study was similar to a study done by Ara G et al. [16]. Another study from south India reported the prevalence of A2 and A2B to be $3.01 \%$ and $1.43 \%$ respectively [2]. Similar study under taken by chaitanya kumar et al. from Andra Pradesh, concluded that prevalence of A2 and A2B is $0.85 \%$ and $1.21 \%$ respectively [17].

Previous study from Karnataka showed that the prevalence of A2 and $\mathrm{A} 2 \mathrm{~B}$ along with $\mathrm{Rh}$ negative status is rare [13]. In general, Indian population the sub type $\mathrm{A} 2 \mathrm{~B}$ is found to be $0.9 \%$ to $1 \%$. The $\mathrm{Rh}$ negative blood groups are found in $15 \%$ of the population [3]. Considering both, the prevalence of $\mathrm{A} 2 \mathrm{~B}$ negative is $0.1 \%$. In our present study $\mathrm{A} 2 \mathrm{~B}$ negative was found to be $0.11 \%$, A2 negative was found to be $0.24 \%$, among all donors during the study period (Table 1B). A similar study from North Karnataka region [15], reported prevalence of A2B negative to be $0.014 \%$ whereas A2 negative was found to be $0.004 \%$. These studies are similar to ours in terms of frequency of A1 and A2 indicating there by that $\mathrm{A} 2$ frequency is much lower compared to $\mathrm{A} 1$ [18]. However, if there is antibody development to A1 in A2 individuals, then for subsequent transfusion one has to be careful to find out the sub-group.

\section{Conclusion}

It seems from the present study that it is important to classify A1 and $\mathrm{A} 2$ and Weak D regularly in the blood bank to avoid transfusion reaction and allo-immunization.

\section{References}

1. Agrawal A, Tiwary AA, Mehta N, Bhattacharay P, Wankhede R, et al. (2014) $A B O$ and $R h(D)$ group distribution and gene frequency; the first multicentric study in india. Asian J of Transfus Sci 8: 121-25.

2. Das PK, Nair SC, Harris VK, Rose D, Mammen JJ, et al. (2001) Distribution of $A B O$ and $R h-D$, Blood groups among blood donors in a tertiary care centre in South India. Trop Doct 1: 47-48.

3. Sharma DC, Rai S, lyenger S, Jain B, Sao S (2013) Prevalence and distribution of $A B O$ and $R h-D$ antigens along with its subgroups and rare types in greater Gwalior region. Open J Blood Dis 2: 69-73.

4. Hussain R, Fareed M, Shah A, Afzal M (2013) Prevalence and gene frequencies of $A 1, A 2$ and $R h(D)$ blood group alleles among some Muslim populations of North India. Egypt J Med Hum Genet 14: 69-76.

5. AABB Technical Manual (2002) ABO, H, and Lewis Blood Groups and Structurally Related antigens (13thedn), pp: 229-253.

6. Hillier CD, Silberstein, Ness, Anderson, Roback (2009) Blood Banking and Transfusion Medicine, Basic Principle \& Practice.

7. Blackwell Scientific Publication (2005) Blood Transfusion in Clinical Medicine The Rh Blood Group System, pp: 173

8. Blackwell Scientific Publication (2005) Blood Transfusion in Clinical Medicine $\mathrm{ABO}$ Lews and $\mathrm{P}$ blood groups and li antigens pp:115.

9. Chandra T, Gupta A (2012) Frequency of $A B O$ and rhesus blood groups in blood donors Asian J Transfus Sci 6: 52-3.

10. Nanu A, Thapliyal RM (1997) Blood group gene frequency in selected north India population. Indian J Med 106:242-6. 
Citation: Pradhan PK, Mishra SC, Patnaik BK, Mohanty D (2019) Prevalence of ABO and RH Blood Group and Sub-Group A1 and A2 in Blood Donors of Odisha - Experience of One Tertiary Centre. J Blood Lymph 9: 249.

11. Periyavan S, Sangeetha SK, Marimuthu P, Manjunath BK, Seema DM (2010) Distribution of $A B O$ and Rhesus-D blood groups in and around Bangalore. Asian J Transfus Sci 4: 41

12. Falusi AG, Ademowo OG, Latunji CA, Okeke AC, Olatunji PO, et al. (2000) Distribution of $A B O$ and Rh genes in Nigeria. Afr J Med Sci 29: 23-6.

13. Reid M, Lomas-Francis C (2003) The Blood Group Antigen FactsBook (2ndedn), Elservier Academic Press pp: 23-24.

14. Azarfarin R, Asl AA (2009) Management of A2B blood group in a patient for hypothermic cardiopulmonary bypass surgery. Middle East J Anaesthesiol 20: $101-3$

15. Giriyan SS, Agrawal A, Bajpai R, Nirala NK (2017) A1 and A2 Sub-Type of
Blood group 'A': A Reflection of their Prevalence in North Karnataka Region. J Clin and Diagn Res 11: 40-2.

16. Ara G, Siddique YH, Afzal M (2011) Some observations on genetic diversity and microdifferentiation processes among some populations of North India Using ABO subtypes and Rh markers. Adv Biol Res 5: 260-66.

17. Kumar ISC, Yashovardhan A, Babu BS, Verma A, Babu KVS, et al. (2012) The prevalence of $A 2$ and $A 2 B$ subgroups in blood donors at a tertiary care teaching hospital blood bank of Rayalaseema region: a pilot study. J Clin Sci Res.

18. Mahapatra S, Mishra D, Sahoo D, Sahoo BB (2016) Study of Prevalence of A2 $\mathrm{A} 2 \mathrm{~B}$ along with major $\mathrm{ABO}$ Blood Groups to minimize the transfusion reactions. Int J Sci Res 5. 